\title{
PERBANDINGAN KEAKTIFAN SISWA DALAM PEMBELAJARAN SISTEM HOME VISIT DAN SISTEM DARING
}

\author{
Siti Rahmania ${ }^{1}$, Luthfi Hamdani Maula ${ }^{2}$, Irna Khaleda ${ }^{3}$ \\ ${ }^{123}$ PGSD FKIP Universitas Muhammadiyah Sukabumi \\ 1 sitirahmania1999@gmail.com , 2 lutfihamdani@ummi.ac.id, \\ 3irnakhaleda@ummi.ac.id,
}

\begin{abstract}
The aim of this study is to determine the difference between home visit and online student learning activities. This research uses a descriptive and comparative quantitative approach. The population of this research is the students of SDN 4 Cisande Kab. Sukabumi and students of SDN Gunung Puyuh CBM Sukabumi City. The sampling technique used is purposive sampling where the sampling technique of the data source is carried out with certain considerations and in this case is 25 students of SDN 4 Cisande Kab. Sukabumi and 25 students of SDN Gunung Puyuh CBM Sukabumi. Data collection techniques in this study used a questionnaire. The data analysis technique used validity test, reliability test, normality test and hypothesis test using independent sample T-test. The results showed that there was a difference between home visit learning and online learning, as evidenced by the $p$ value (sig(2-tailed)) on the home visit learning variable of $0.828>0.05, p$ (sig(2tailed)) on the variable online learning is $0.828>0.05$.
\end{abstract}

Keywords: Learning Activity; Home Visits; Online.

\section{ABSTRAK}

Tujuan dalam penelitian ini yaitu untuk mengetahui perbedaan keaktifan belajar siswa Home visit dan Daring. Penelitian ini menggunakan jenis penelitian metode deskriptif dan komparatif pendekatan kuantitatif. Populasi yang menjadi penelitian ini ialah siswa SDN 4 Cisande Kab. Sukabumi dan siswa SDN Gunung Puyuh CBM kota Sukabumi. Teknik pengambilan sampel yang digunakan yaitu Purposive Sampling dimana teknik pengambilan sampel sumber datanya dilakukan dengan pertimbangan tertentu dan dalam hal ini yaitu adalah 25 Siswa SDN 4 Cisande Kab. Sukabumi dan 25 siswa SDN Gunung Puyuh CBM kota Sukabumi. Teknik pengumpulan data dalam penelitian ini menggunakan angket. Teknik analisis data menggunakan uji validitas, uji reliabilitas, uji normalitas dan uji hipotesis menggunakan independent sample T-test. Hasil penelitian menunjukan bahwa terdapat perbedaan antara pembelajaran home visit dan pembelajaran daring, dibuktikan dengan nilai $\mathrm{p}$ (sig(2-tailed)) pada variabel pembelajaran home visit sebesar $0,828>0,05, \mathrm{p}(\mathrm{sig}(2$-tailed)) pada pada variabel pembelajaran daring sebesar 0, $828>0,05$.

Kata Kunci: Keaktifan Belajar; Home Visit; Daring. 


\section{A. Pendahuluan}

Pendidikan yakni suatu aktivitas yang kompleks, berukuran luas serta banyak variabel yang mempengaruhinya.

Pempembelajaranan bisa dimaksud pula selaku sesuatu proses interaksi antara guru dengan siswa untuk menggapai tujuan tertentu. Tujuan dari pendidikan yakni untuk tingkatkan keahlian dan tingkatkan kualitas kehidupan serta martabat manusia dalam mewujudkan tujuan nasional. Pendidikan hakikatnya ialah suatu sistem yang dicoba secara semesta yang didukung oleh keluarga, masyarakat serta pemerintah. Pendidikan hakikatnya merupakan suatu sistem yang dilakukan secara semesta yang didukung oleh keluarga, masyarakat dan pemerintah. Pendidikan merupakan salah satu faktor yang berfungsi untuk meningkatkan kualitas sumber daya manusia (Hidayati 2016). Sumber daya manusia yang berkualitas dapat menjadikan pengelolaan sumber daya alam dan pemberian layanan yang efektif dan efisien dalam meningkatkan kesejahteraan dalam masyarakat (Anggraeni, 2019). Prinsip dasar pendidikan ialah mendidik, mengarahkan, membina serta memimpin anak sehingga harapannya mereka mempunyai kebahagiaan hidup yang seluas- luasnya. Prinsip dasar pendidikan merupakan tujuan serta harapan dari guru dan orang tua bagi para siswa dimasa yang akan datang.

Tertulis dalam hadis :

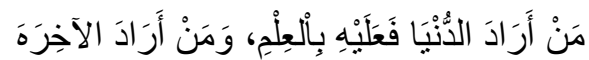

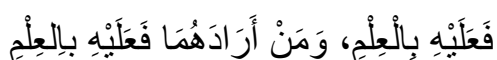

"Barangsiapa yang hendak menginginkan dunia, maka hendaklah ia menguasai ilmu. Barangsiapa menginginkan akhirat, hendaklah ia menguasai ilmu. Dan barang siapa yang menginginkan keduanya (dunia dan akhirat), hendaklah ia menguasai ilmu." (HR. Ahmad).

Bulan Maret tahun 2020 World Health Organization (WHO) mengumumkan bahwa dunia sedang dilanda penyakit yang beresiko. Penyakit yang disebutkan oleh WHO ialah Corona Virus Diseases 2019 (Covid-19). WHO menyatakan Covid19 sebagai pandemic global. Indonesia menjadi salah satu negara yang terpapar Covid-19, sehingga Pemerintah Indonesia menetapkan Covid-19 sebagai bencana nasional non-alam. Pemerintah Indonesia membuat berbagai kebijakan untuk 
mengatasi Covid-19. Pandemic Covid-19 merupakan musibah yang memilukan bagi seluruh penduduk bumi. Seluruh kehidupan di bumi terganggu, tanpa terkecuali pendidikan.

Home Visit ialah metode pembelajaran dengan cara pembagian kelompok sesuai domisili siswa. Tujuan metode Home Visit ialah untuk memudahkan siswa dalam pembelajaran tatap muka bersama teman dan guru. Menurut Sudrajat (2011) Kunjungan rumah atau Home Visit ialah berkunjung kerumah siswa untuk membantu menyelesaikan problem yang dialami oleh siswa, dalam langkah mencari dan melengkapi data atau informasi siswa. Home Visit ialah kegiatan yang dilakukan untuk mengetahui data komitmen dalam rangka menyelesaikan problem siswa. Data yang diambil berupa keadaan siswa ketika dirumah, hubungan siswa dengan keluarga, kebiasaan siswa, fasilitas yang ada dirumah, serta komitmen orang tua dalam perkembangan anaknya. Kerjasama guru dan orang tua atau wali murid serta masyarakat sangat dibutuhkan untuk membangun keaktifan siswa dengan metode pembelajaran Home
Visit. Kunjungan Home Visit ialah salah satu program sekolah. Tujuan pempembelajarann Program Home Visit diharapkan dapat tercapai dengan baik. Berikut ini disajikan kelebihan serta kekurangan dari program Home Visit Kelebihan pembelajaran Home Visit ialah : penyampaian materi sesuai dengan tujuan yang diharapkan, guru lebih mudah menilai sikap siswa, materi yang disampaikan oleh guru lebih mudah dipahami siswa, dan interaksi siswa dengan guru, siswa dengan siswa lebih leluasa tanpa ada batasan media. Kekurangan dari pembelajaran Home Visit ialah : bahan ajar yang akan dipelajari siswa terbatas dan materi tidak dapat tersampaikan secara menyeluruh karena keterbatasan waktu.

Hasil obeservasi yang dilakukan di SDN 4 Cisande, peneli melihat pempembelajaranan menggunakann sistem Home Visit yang dimana proses pempembelajaranannya dengan cara pembagaian kelompok sesaui dengan tempat tinggal siswa agar memudahkan pertemuan siswa dengan siswa, siswa dengan guru menjadi lebih mudah dan tetap mematuhi protocol kesehatan. 
Didaktik : Jurnal IImiah PGSD STKIP Subang, ISSN Cetak : 2477-5673 ISSN Online : 2614-722X Volume 07 Nomor 01, Juni 2021

Observasi selanjutnya peneliti melakukan di SDN Gunungpuyuh CBM dengan proses pempembelajarann menggunakann sistem Daring, dengan memanfaatkan TI untuk mendukung pempembelajaranan.

Hasil pengamatan peneliti terhadap keaktifan pembelajaran melalui metode Home Visit dan Daring siswa di SDN Gunung Puyuh CBM Kota Sukabumi dan SDN 4 Cisande kecamatan Cicantayan Kab. Sukabumi ditemukan beberapa perbedaan keaktifan siswa dalam kegiatan pempembelajaranan. Maka dari itu peneliti tertarik untuk meneliti masalah yang berjudul "Perbandingan Keaktifan Siswa Dalam Pempembelajaranan Sistem Home Visit Dan Sistem Daring"

\section{B. Metode Penelitian}

Penelitian ini dilaksanakan di dua sekolah yaitu SDN 4 Cisande Kecamatan Cicantayan Kab. Sukabumi dan SDN 4 Cisande Kecamatan Cicanatayan Kab. Sukabumi. Metode yang digunakan dalam penelitian ini adalah dekskriptif dengan pendekatan kuantitatif.

Teknik pengumpulan data dalam penelitian ini menggunakann angket langsung. Angket adalah alat untuk mengumpulkan data berupa daftar pertanyaan yang disampaikan kepada responden untuk dijawah secara tertulis. (Winarni, 2018:70). Pada penelitian ini menggunakan skala Likert sebagai skala jawaban untuk kuesioner. Sugiyono (2015:134) mengemukakan bahwa skala Likert merupakan skala yang digunakan untuk mengukur sikap, pendapat, dan persepsi seseorang atau sekelompok orang tentang fenomena sosial.

Pada penelitian ini, analisis data yang digunakan yaitu uji prasyarat analisis dan uji independent sample ttest.

\section{C.Hasil Penelitian dan Pembahasan} Instrument pernyataan keaktifan siswa dalam pembelajaran sistem Home Visit dan sistem daring dilakukan uji coba oleh 25 siswa SDN 9 Cibadak Kabupaten Sukabumi. Dari hasil perhitungan validasi, diperoleh 30 butir pernyataan keaktifan siswa dalam pembelajaran sistem Home Visit dan 30 butir pernyataan keaktifan siswa dalam pembelajaran sistem daring. Kemudian, peneliti menyebar kuisioner terhadap responden dalam pembembelajan sistem Home Visit di SDN 4 Cisande Kabupaten Sukabumi dengan jumlah responden 25 siswa, 
dengan mendatangi salah satu rumah yang sedang digunakan untuk pembelajaran. Kemudian peneliti menyebarkan kuisioner terhadap responden dalam pembelajaran sistem Daring di SDN Gunungpuyuh CBM Kota Sukabumi dengan jumlah responden 25 siswa, dengan menyebarkan kuisioner Online melalui google form.

Setelah melakukan uji coba instrument, kemudian peneliti melakukan pengumpulan data. Teknik pengumpulan data pada penelitian ini yaitu menggunakan angket. Pengumpulannya dengan menggunakan angket pada semua responden/siswa dan dilakukan hanya sekali dalam waktu yang bersamaan, responden/siswa diberi angket dan mengisi angket dengan peneliti mendampingi. Data yang telah terkumpul kemudian diberi skor dan dihitung nilainya. Data yang telah terkumpul, kemudian peneliti olah dengan menggunakan SPSS Versi 26 for windows. Adapun pada penelitian ini, analisis data yang digunakan yaitu uji prasyarat analisis, dan uji Independent Sample T Test.

Hasil uji normalitas pada variabel pembelajaran home visit dan pembelajaran daring dengan uji
Kolmogorov-Smirnov dan ShapiroWilk, baik pada variable pembelajaran home visit dan pembelajaran daring menunjukan hasil bahwa data berdistribusi normal. Setelah uji normalitas, tahap selanjutnya yaitu uji Independent Sample $\mathrm{T}$ Test. Uji Independent Sample $T$ Test digunakan untuk mengetahui perbedaan dari pembelajaran home visit dan pembelajaran daring. Dari hasil Uji Independent Sample T Test menunjukan bahwa terdapat perbedaan antara pembelajaran home visit dan pembelajaran daring.

Setelah peneliti melakukan penelitian, terhadap siswa yang pembelajaran menggunakan sistem Home Visit yang dapat dideskripsikan bahwa pembelajaran dalam sistem Home Visit terdapat kelebihannya, yaitu : 1) siswa lebih mudah berinteraksi dengan guru maupun temannya, 2) guru lebih mudah menilai sikap spiritual siswa, 3) siswa lebih mudah menyerap penjelasan materi yang dijelaskan guru, 4) emosional siswa dengan guru lebih terkontrol, 5) interaksi siswa dengan siswa lebih mudah. Adapun kekurangannya, yaitu : 1) jadwal pembelajaran tidak sesuai dengan 
kurikulum, 2) terhambatnya akses yang ditempuh oleh guru, 3 )

Kemudian peneliti melakukan penelitian terhadap siswa yang menggunakan pembelajaran sistem Daring terdapat kelebihannya, yaitu : 1) siswa lebih mandiri dalam proses pembelajaran, 2) guru lebih kreatif dalam memberikan penjelasan, 3) mendorong siswa lebih mengikuti berkembangan sistem pembelajaran sekarang, 4) siswa lebih kreaktif dalam menggapi penjelasan dari guru, 5) Guru dan siswa dapat berkomunikasi secara mudah melalui internet kapan saja kegiatan berkomunikasi itu dilakukan tanpa dibatasi oleh jarak, tempat, dan waktu. Adapun kekurang dari pembelajaran sistem Daring, yaitu : 1) interiaksi siswa dengan siswa, siswa dengan guru terbatas oleh ruang, 2) terhambatnya signal, 3) siswa lebih cenderung membuka aplikasi lain saat pembelajaran berlangsung, 4) guru diharuskan menguasi Teknik pembelajaran ICT (Information Communication Technology).

\section{E. Kesimpulan}

Berdasarkan analisis data, pengujian hipotesis serta hasil dan pembahasan yang telah dikemukakan peneliti dapat diambil simpulan sebagai berikut. Hasil uji normalitas pada variabel pembelajaran home visit dan pembelajaran daring dengan uji Kolmogorov-Smirnov dan ShapiroWilk, baik pada variabel pembelajaran home visit dan pembelajaran daring menunjukan hasil bahwa data berdistribusi normal. Dari hasil Uji Independent Sample $T$ Test menunjukan bahwa terdapat perbedaan antara pembelajaran home visit dan pembelajaran daring.

Berdasarkan hasil penelitian yang telah dilakukan, maka peneliti memberikan saran sebagai berikut.

1) Pihak sekolah hendaknya meningkatkan keterampilan guru dalam mengimplementasikan sistem pembelajaran daring di masa Pandemi Covid-19 ini.

2) Pihak guru, hendaknya perlu terus berinovasi dalam mengajar, penguasaan kompetensi pedagogik guru, terutama keterampilan Pembelajaran dalam jaringan mencakup seluruh indikator di dalamnya dari berbagai sumber informasi.

3) Pihak luar, penelitian ini diharapkan dapat dijadikan sebagai sarana informasi sehingga dalam penelitian selanjutnya dapat 
memperbaiki keterbatasan yang ada dalam penelitian ini dengan melakukan penelitian pada lokus penelitian yang berbeda dan memperluas variabel mengenai pembelajaran home visit dan pembelajaran daring agar dapat mengembangkan penelitian dengan menggunakan variabel lain, sehingga dapat mendukung dalam penelitian selanjutnya.

\section{DAFTAR PUSTAKA}

Dwita, K. D., Anggraeni, A. I., \& Haryadi. (2018). Pengaruh Home Visit dan Motivasi Belajar Terhadap Hasil Belajar Siswa di SDIT Harapan Bunda Purwokerto. Jurnal Ekonomi, Bisnis, Dan Akuntansi, 20(01), 115.

Hidayati, U. (2016). Analisis kesesuaian antara metode motivasi dengan motivasi kerja salesman Auto 2000 Probolinggo dengan menggunakan teori Herzberg. Analisis kesesuaian antara metode motivasi dengan motivasi kerja salesman Auto 2000 Probolinggo dengan menggunakan teori Herzberg/Ulfa Hidayati.

Sudrajat. (2011). Mengatasi Masalah Siswa Melalui Layanan Konseling Individual. Yogyakarta: Paramita Publishing.

Sugiyono. (2015). Metode Penelitian Pendidikan. Alfabeta. 